\title{
THE ROLE OF FUEL VOLATILES FOR THE EMISSION OF NITROGEN OXIDES FROM FLUIDIZED BED BOILERS- A COMPARISON BETWEEN DESIGNS
}

\author{
L-E. AMMAND AND B. LECKNER \\ Chalmers University of Technology \\ Department of Energy Conversion \\ S-412 96 Göteborg, Sweden
}

\begin{abstract}
The nitrogen oxides formed during fluidized bed combustion of solid fuels originate from fuel nitrogen in both char and volatiles. In the course of combustion these fuel constituents not only contribute to the production but also take part in the reduction of the emission.

In order to study the role of the nitrogen-containing volatiles for the production and reduction of nitrogen oxides in fluidized bed boilers a series of tests has been carried out with fuels having different contents of volatiles in a range from anthracite to wood in two types of boiler, a circulating and a stationary fluidized bed boiler.

It was found that the different designs of boilers result in different behaviours of the nitrogen-containing volatiles. In stationary fluidized bed boilers the volatiles tend to reduce the emissions of NO comparable to what takes place in a pulverized coal flame, whereas in circulating fluidized bed boilers the volatiles do not have the same beneficial effect. In circulating fluidized bed boilers the emission of NO tends to increase with an increasing content of volatiles in the fuel, whereas the emission decreases from the stationarry fluidized bed type of boiler burning fuels with a larger amount of volatiles.
\end{abstract}

\section{Introduction}

Solid fuel combustion is characterized by the evolution and combustion of fuel volatiles and by combustion of the char residue. The nitrogen oxides formed during combustion in a fluidized bed originate from fuel nitrogen in both char and volatiles. In the course of combustion the nitrogencontaining volatiles may contribute to the reduction of nitrogen oxides. The volatiles not containing nitrogen and combustion products from char in the form of carbon monoxide and hydrogen may also take part in the reduction of nitric oxide by reactions catalyzed by char and other surfaces which are available, especially in the particle bed of a fluidized bed combustor. Furthermore, char itself reacts with nitric oxide to form nitrogen. In summary, char as well as volatiles play decisive roles for the formation and destruction of nitrogen oxides in solid fuel combustors.

This very simplified picture of the origin of the emissions of nitrogen oxides will be used as a starting point for the explanation of differences in the character of nitrogen oxide emissions from commercial combustors of various designs. The interest is concentrated on circulating fluidized bed (CFB) boilers compared with stationary fluidized bed (SFB) boilers. In addition, the influence of volatiles on the emissions from pulverized fuel (PC) combustion is discussed.

The purpose of the paper is thus to give a picture of the role of fuel volatiles in different combustors. A set of experiments has been conducted in two fluidized bed boilers with different fluidization properties, one SFB and one CFB. The boilers have been fed with fuels having a wide variation in the content of volatiles, from anthracite to wood, and the emissions have been measured. The observations made have been supported by a comparison with literature data. In order to further illustrate the role of volatiles, examples are given from $\mathrm{NO}_{\mathrm{x}}$ reducing measures, where the characteristic properties of the combustors with respect to emissions are employed.

\section{Experimental}

\section{The Boilers:}

The CFB boiler used has a thermal power of 8 MW and was built by Götaverken Energy in 1981, Fig. 1a. The height of the combustion chamber is $8.5 \mathrm{~m}$ and the cross-section about $1.8 \mathrm{~m}^{2}$. The fluidizing velocity is normally in the range of 3 to 6 $\mathrm{m} / \mathrm{s}$. The fuel is fed with a screw feeder in the 


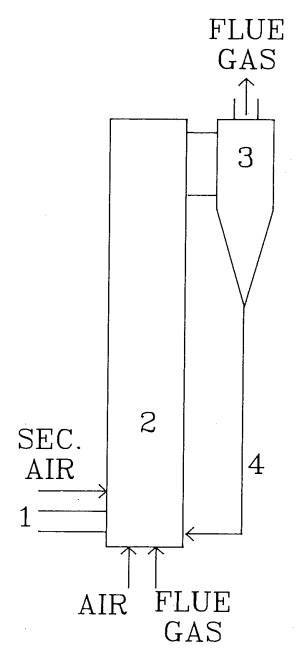

a) Cityvarvet

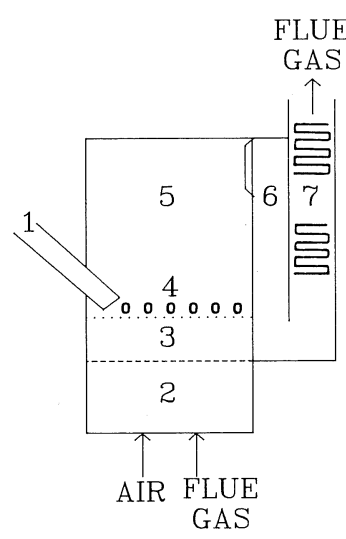

b) Chalmers
FIG. 1. Schematic picture of the boilers

a) Cityvarvet. 1-Fuel feed screw, 2-Combustion chamber with fluidized bed, 3-Cyclone, 4Particle return leg

b) Chalmers. 1-Fuel feed chute, 2-Air plenum, 3-Fluidized bed, 4-Secondary air nozzles, 5Freeboard, 6-Empty gas pass, 7-Convection gas pass

lower part of the combustion chamber close to the bottom. Secondary air is introduced through an air register as shown in Fig. 1a. The bed particles are recirculated to the combustion chamber by a hot cyclone. External recirculation of particles from a secondary fly-ash collector is possible, but is not normally employed. Silica sand and ashes were used as a bed material and no limestone was added during the experiments.

The SFB boiler is a 16 MW boiler built in 1982 at Chalmers University. The features of this boiler are shown in Fig. 1b. The characteristic data are: cross-section $10 \mathrm{~m}^{2}$, bed depth $1 \mathrm{~m}$, height of freeboard $4 \mathrm{~m}$, fluidizing velocity during the present tests $1.5 \mathrm{~m} / \mathrm{s}$. The fuel is fed on to the surface of the bed. Secondary air can be supplied through a number of nozzles as indicated in the figure. The bed material was of the same type as that of the CFB.

\section{The Fuels:}

A range of fuels has been selected, from anthracite with $11 \%$ of volatiles to wood chips with $86 \%$ of volatiles. The properties of the fuels are presented in Table I.

The wood chips were delivered in the form of non-uniform pieces about $20 \mathrm{~mm}$ in length and 5 mm thick. The peat consisted of cylinders, diameter $70 \mathrm{~mm}$, length 100 to $150 \mathrm{~mm}$. Some of the cylinders were broken into pieces, producing a fine fraction corresponding to about $10 \%$ of the fuel fed. The brown coal was also supplied in the form of cylinders with a diameter of $60 \mathrm{~mm}$ and a length of $35 \mathrm{~mm}$.

Special care has been given to the analysis of the nitrogen content of the fuel since the results are presented as conversion of fuel nitrogen to NO. The calculation of the nitrogen conversion is based on the amount of fuel nitrogen that is released in the combustion chamber and converted to NO. A conversion of $1 \%$ of the fuel nitrogen to NO corresponds (in the case of bituminous coal) to a concentration in the order of $20 \mathrm{ppm} \mathrm{NO}$ at $6 \% \mathrm{O}_{2}$ (dry).

\section{The Tests:}

During the tests the boilers were run at constant operating conditions equal to the ones normally employed for boiler operation, with one exception, that the excess air ratio of the CFB boiler was 1.1 instead of 1.25. The deviation from the desired value was caused by an error in the excess air measurement for boiler operation, which was discovered after the tests and corrected for. Tables II and III give the principal data. It can be deduced from the tables that not only the CFB boiler but also the SFB boiler was run with some secondary air. Flue gas recirculation was employed in order to maintain a constant bed temperature when using fuels with different moisture content and heating values. For the same reason some coal had to be added with the wood. The duration of each test was one to two hours, starting when the boilers had attained stationary conditions.

The gas analyses were taken with conventional, calibrated gas analysers after the convection pass in the SFB and after the cyclone just before the convection pass in the CFB. The flue gas flow was calcualted by means of the oxygen concentration at the location of the gas sampling. The results are presented in the form of a conversion to NO since the emission of $\mathrm{NO}_{2}$ is negligible and $\mathrm{N}_{2} \mathrm{O}$ has been considered separately ( $\mathrm{Amand} \&$ Andersson $^{10}$ ).

\section{Results}

The conversion of fuel nitrogen to NO in the SFB boiler is shown in Fig. 2. It is evident that the volatile content of the fuel has a positive effect on the reduction of the emission of NO.

The corresponding results for the $\mathrm{CFB}$ boiler are presented in Fig. 3. The influence of volatiles, although leading to a more complicated relationship, does not on the whole have the same trend as in 
TABLE I

The fuels

\begin{tabular}{|c|c|c|c|c|c|c|}
\hline Type & $\begin{array}{l}\text { Wood }^{\mathrm{a}} \\
\text { chips }\end{array}$ & Peat $^{b}$ & $\begin{array}{c}\text { Brown } \\
\text { coal }\end{array}$ & $\begin{array}{c}\text { Bitu- } \\
\text { minous } \\
\text { coal }\end{array}$ & $\begin{array}{l}\text { Petro- } \\
\text { leum } \\
\text { coke }\end{array}$ & $\begin{array}{l}\text { Anth- }{ }^{\mathrm{a}} \\
\text { racite }\end{array}$ \\
\hline Size, mm, mass mean & & - see text- & & 6.5 & 7 & 1.9 \\
\hline$\%<1 \mathrm{~mm}$ & 0 & 10 & 0 & 11 & 14 & 50 \\
\hline Volatiles, \% maf & 86.0 & 72 & 53.1 & 35.5 & 14.3 & 11.1 \\
\hline \multicolumn{7}{|c|}{ Prox. anal, $\%$ as delivered: } \\
\hline Combustibles & 64.7 & 48.6 & 80 & 87 & 91 & 74.0 \\
\hline Ash & 0.04 & 3.2 & 5 & 7 & 2 & 6.4 \\
\hline Moisture & 35.3 & 48.2 & 15 & 6 & 7 & 19.6 \\
\hline \multicolumn{7}{|l|}{ Ultimate anal., \% maf: } \\
\hline $\mathrm{C}$ & 51.1 & 56.3 & 67.5 & 82.7 & 89.8 & 92.1 \\
\hline $\mathbf{H}$ & 6.3 & 4.6 & 4.9 & 5.2 & 4.1 & 1.6 \\
\hline $\mathrm{O}$ & 42.3 & 36.5 & 25.9 & 8.8 & 2.7 & 2.6 \\
\hline $\mathrm{S}$ & 0.03 & 0.5 & 0.8 & 1.6 & 2.0 & 2.3 \\
\hline $\mathrm{N}$ & 0.3 & 2.0 & 0.9 & 1.7 & 1.4 & 1.4 \\
\hline $\begin{array}{l}\text { Heating value, lower, } \\
\mathrm{MJ} / \mathrm{kg} \text { maf }\end{array}$ & 18.8 & 21.8 & 25.7 & 33.1 & 35.4 & 32.0 \\
\hline
\end{tabular}

${ }^{a}$ CFB (Cityvarvet only).

${ }^{\mathrm{b}} \mathrm{SFB}$ (Chalmers only).

the SFB. The trend is rather reversed-a high volatile content leads to a high $\mathrm{NO}$ emission. It is also noted that there is a minimum of conversion for fuels with properties like bituminous coals.

The NO emission is susceptible to a variety of design and operating parameters which are not easily controlled or even identified. For that reason, a confirmation of the results with independent tests is desirable. A number of tests comprising different fuels can be found in the literature. The principal data from these tests are given in Tables II and III and the corresponding comparison with the data of the present investigation is made in Fig. 4 and Fig. 5 .

\section{TABLE II}

Key to Fig. 4. Comparison of the influence of fuel volatiles on the fuel nitrogen conversion to NO between different SFBs

\begin{tabular}{|c|c|c|c|c|c|}
\hline & $\begin{array}{c}\text { Hampartsoumian }^{1} \\
\text { B } \\
* \ldots * \ldots *\end{array}$ & $\begin{array}{l}\text { Furusawa }^{2} \\
\text { E } \\
\text { O--O--O }\end{array}$ & $\begin{array}{c}\text { Wittler }^{3} \\
\text { D } \\
+--+--+\end{array}$ & $\begin{array}{c}\text { Asai }^{4,5} \\
\text { C } \\
-\end{array}$ & $\begin{array}{l}\text { This work } \\
\text { A } \\
\text { *. . . *. . .* }\end{array}$ \\
\hline $\begin{array}{l}\text { Bed temp. }{ }^{\circ} \mathrm{C} \\
\text { Excess air ratio } \\
\text { Prim. air stoich. } \\
\text { Bed area } \mathrm{m}^{2} \\
\text { Height, furnace, m } \\
\text { Ca/S } \\
\text { Fuels used } \\
\text { (Volatiles } \\
\text { within brackets } \\
\text { given on } \\
\text { maf basis) }\end{array}$ & $\begin{array}{c}<800-850 \\
1.25 \\
1.25 \\
0.3 \\
2 \\
0 \\
\text { Anthracite } \\
(7.64) \\
\text { Bituminous coal } \\
(37.8) \\
\text { Peat } \\
(67.9)\end{array}$ & $\begin{array}{c}1000 \\
1.30 \\
1.30 \\
0.002-0.005 \\
0.5-0.85 \\
0 \\
\text { Char } \\
(3.99) \\
\text { Char } \\
(19.2) \\
\text { Bit. coal } \\
\text { (52.6) }\end{array}$ & $\begin{array}{c}850 \\
1.25 \\
1.25 \\
0.3 \\
1.3 \\
0 \\
\text { Anthracite } \\
\text { (9.15) } \\
\text { Engl. coal } \\
(36.7) \\
\text { Pol. coal } \\
(34.4) \\
\text { Ruhr coal } \\
(37.2)\end{array}$ & $\begin{array}{c}830 \\
1.25 \\
1.25 \\
0.3 \\
4 \\
\text { unknown } \\
\text { Semianthr } \\
\text { (12.4) } \\
\text { Bit. coal } \\
\text { (44.5) } \\
\text { Ind. waste } \\
\text { (84.5) }\end{array}$ & $\begin{array}{c}845 \\
1.25 \\
1.10 \\
10 \\
5 \\
0 \\
\text { Pet. coke } \\
\text { (14.4) } \\
\text { Bit. coal } \\
\text { (35.5) } \\
\text { Brown coal } \\
(53.1) \\
\text { Peat } \\
(72.1)\end{array}$ \\
\hline
\end{tabular}


TABLE III

Key to Fig. 5. Comparison of the influence of fuel volatiles on the fuel nitrogen conversion to NO between different CFBs

\begin{tabular}{|c|c|c|c|c|c|c|}
\hline & $\begin{array}{c}\text { Asai }^{5} \\
\mathrm{C} \\
\mathrm{O}--\mathrm{O}--\mathrm{O}\end{array}$ & $\begin{array}{c}\text { Suzuki }^{6} \\
\text { B } \\
\times--\times--\times\end{array}$ & $\begin{array}{l}\text { Shimuzu }^{7} \\
\text { E } \\
\text { O-O-O }\end{array}$ & $\begin{array}{c}\text { Lee }^{8} \\
\text { D } \\
+-+-+\end{array}$ & $\begin{array}{c}\text { Legros }^{9} \\
\mathrm{~F} \\
-\end{array}$ & $\begin{array}{l}\text { This work } \\
\text { A } \\
* \ldots * \ldots *\end{array}$ \\
\hline $\begin{array}{l}\text { Bed temp. }{ }^{\circ} \mathrm{C} \\
\text { Excess air ratio } \\
\text { Prim. air stoich } \\
\text { Bed area } \mathrm{m}^{2} \\
\text { Height, furnace, m } \\
\mathrm{Ca} / \mathrm{S} \\
\text { Fuel used } \\
\text { (Volatiles } \\
\quad \text { within brackets } \\
\text { given on } \\
\text { maf basis) }\end{array}$ & $\begin{array}{c}830 \\
1.25 \\
1.25 \\
0.03 \\
7.6 \\
\text { unknown } \\
\text { Semianthr } \\
\text { (12.4) } \\
\text { Bit. coal } \\
\text { (44.5) } \\
\text { Ind. waste } \\
\text { (84.5) }\end{array}$ & $\begin{array}{c}850-870 \\
1.2 \\
\text { unknown } \\
0.009 \\
5 \\
2 \\
\text { Coke } \\
(2.56) \\
\text { Semianthr. } \\
(14.2) \\
\text { Low-vol. } \\
\text { coal (21.4) } \\
\text { Medium-vol } \\
\text { coal (28.5) } \\
\text { High-vol. } \\
\text { coal (38.2) } \\
\text { Brown coal } \\
\text { (48.2) }\end{array}$ & $\begin{array}{c}850 \\
1.2 \\
0.7-0.8 \\
0.002 \\
4.3 \\
0 \\
\text { Coke } \\
(14.0) \\
\text { Semianthr. } \\
(13.8) \\
\text { Bit. coal } \\
(43.8) \\
\text { Brown } \\
\text { coal (47.1) }\end{array}$ & $\begin{array}{c}850-920 \\
1.15-1.25 \\
0.7-0.8 \\
\text { unknown } \\
\text { unknown } \\
\text { unknown } \\
\text { Proc. culm. } \\
\text { (9.53) } \\
\text { Pet. coke } \\
(11.2) \\
\text { Sub-bit. } \\
\text { coal (36.4) } \\
\text { Sub-bit. } \\
\text { coal (36.5) } \\
\text { Appalachian } \\
\text { coal (38.4) } \\
\text { Brown coal } \\
\text { (57.9) } \\
\text { Diatomite } \\
\text { (90.9) }\end{array}$ & $\begin{array}{c}850-880 \\
1.15-1.25 \\
0.5-0.8 \\
0.15 \\
7.13 \\
0 \\
\text { Anthracite } \\
(8.37) \\
\text { Minto coal } \\
(41.3) \\
\text { Highvale } \\
\text { coal (42.9) } \\
\text { Lignite } \\
(47.8) \\
\text { Hog fuel } \\
\text { (71.8) }\end{array}$ & $\begin{array}{c}845-850 \\
1.05-1.08 \\
0.7-0.8 \\
1.82 \\
7.8 \\
0 \\
\text { Anthracite } \\
(11.1) \\
\text { Pet. coke } \\
(14.4) \\
\text { Bit. coal } \\
\text { (35.5) } \\
\text { Brown coal } \\
\text { (53.1) } \\
\text { Woodchips / } \\
\text { coal (74.7) }\end{array}$ \\
\hline
\end{tabular}

All the sets of data in Fig. 4 show that an increasing amount of fuel volatiles leads to reduced emissions of NO. The explanation has been given, e.g. by Hampartsoumian and Gibbs, ${ }^{1}$ that nitrogen-

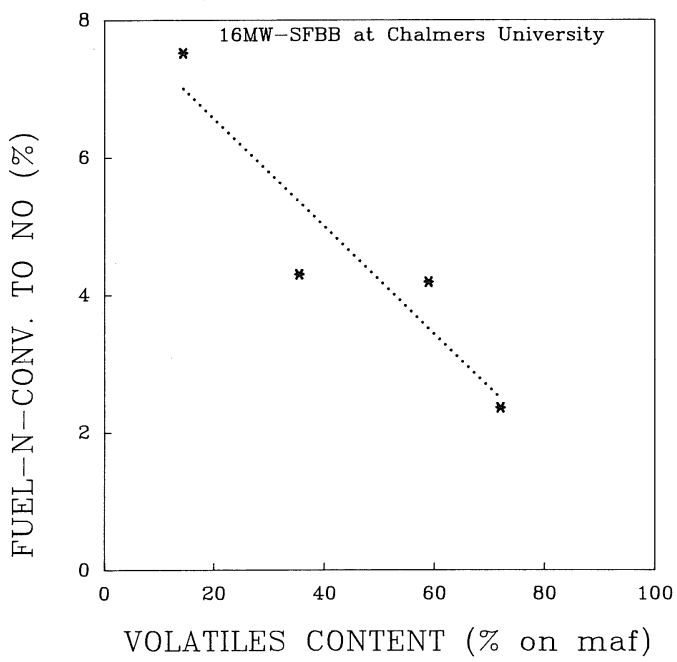

FIG. 2. The conversion of fuel nitrogen to $\mathrm{NO}$ in the stationary fluidized bed boiler during the combustion of fuels with different contents of volatiles. containing volatile compounds, mostly consisting of ammonia, react in the splash zone and in the lower part of the freeboard where the particle concentration is low. They then contribute to the reduction

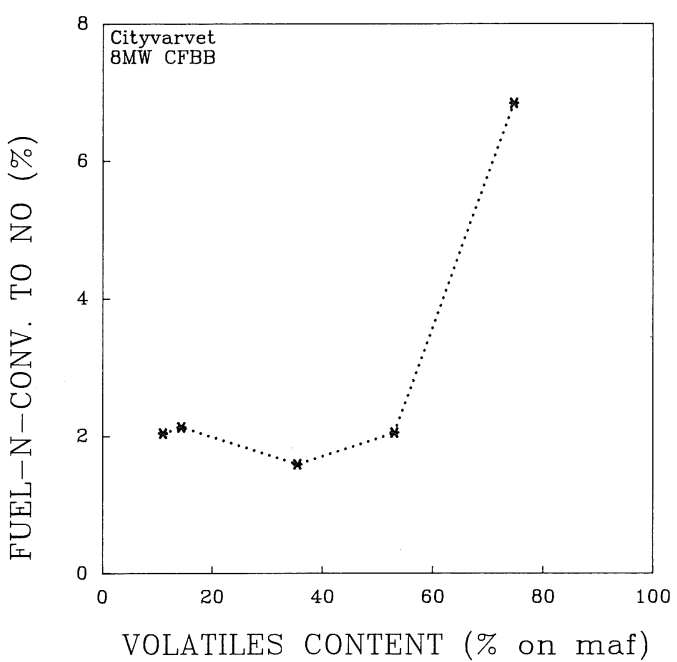

FIG. 3. The conversion of fuel nitrogen to NO in the circulating fluidized bed boiler during the combustion of fuels with different contents of volatiles. 


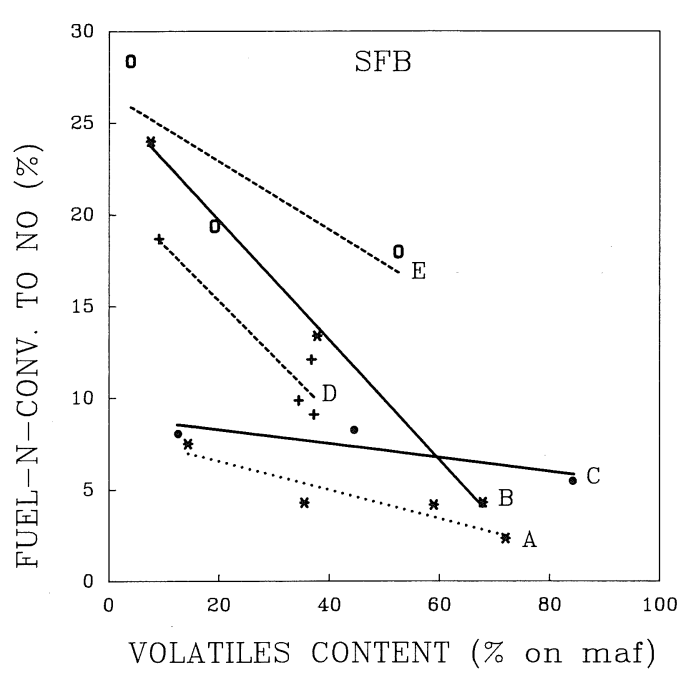

FIG. 4. Influence of fuel volatiles on the conversion ratio of fuel nitrogen to NO. Combustion in stationary fluidized beds. Key: See Table II.

of NO in the case that secondary air is not supplied close to the reaction zone. This has been demonstrated by Hirama et al. ${ }^{11}$ and by Tatebayashi et al. $^{12}$

The sets of data from CFB combustors, Fig. 5, do show the opposite trend compared to the SFB combustors in Fig. 4. The general concept of an explanation for this opposite trend is based on the dominance of char as a reducing agent of $\mathrm{NO}$ in CFBs. The char may consume NO by direct re-

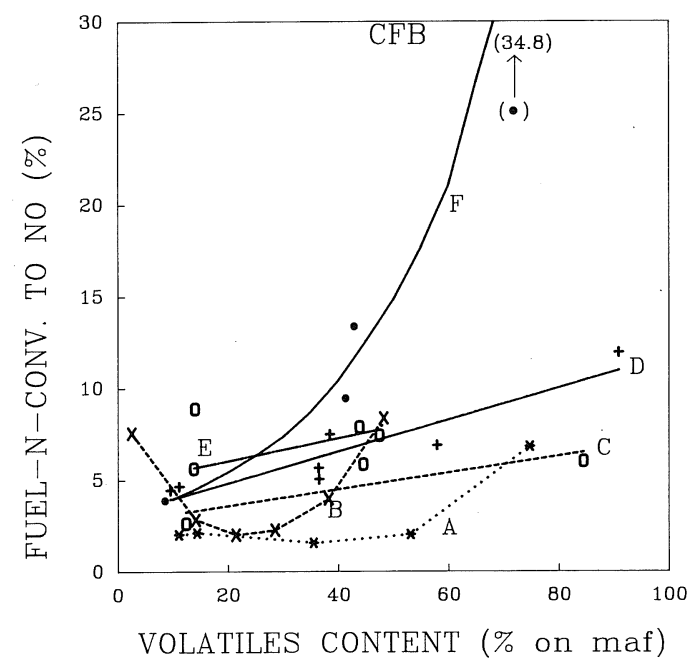

FIG. 5. Influence of fuel volatiles on the conversion ratio of fuel nitrogen to NO. Combustion in circulating fluidized beds. Key: See Table III. action or by acting as a catalyst for the reaction between $\mathrm{NO}$ and $\mathrm{CO}$ or $\mathrm{H}_{2}$. The role of nitrogencontaining volatiles in the reduction of $\mathrm{NO}$, on the other hand, is less important since they tend to be broken down by the surfaces of particles (Hirama et al. $\left.{ }^{11}\right)$. This decomposition takes place particularly on char particles but also on sand, $\mathrm{CaSO}_{4}$ and ashes which are found in concentrations ranging from 1000 $\mathrm{kg} / \mathrm{m}^{3}$ in the bottom to $1-5 \mathrm{~kg} / \mathrm{m}^{3}$ in the top of the furnace.

A fuel containing less fixed carbon results in a lower content of char in the combustion chamber (at constant power), which leads to less char surface for reduction of NO. If the contribution from the volatiles were small there would be an increase in the NO emission with increasingg content of volatiles in the fuel, as in the case of the CFB. On the other hand, based on the above reasoning, in the SFB there must be a positive contribution to NO reduction by the volatiles.

However, this cannot be the whole truth. If the curve for CFB obtained in the present investigation is compared with that of Suzuki et al., ${ }^{6}$ it is found that they both display a minimum. Actually, the data points of Shimuzu ${ }^{7}$ also, if plotted in the same way, would agree with such a behaviour. The explanation of the increase in the conversion of fuel nitrogen to $\mathrm{NO}$ at low volatile fuels is only tentative for the moment:

1. Low-reactive fuels burn in a different way compared to bituminous coals and tend to have more reactions in the pores of the particles, which leads to different NO reduction characteristics $\left(\right.$ Shimuzu $\left.^{7}\right)$.

2. Low volatile fuels produce less volatile-CO. It is however unclear how this influences the reduction of NO on the surfaces of the char, since CO may be produced in sufficient quantities by the combustion of char itself.

Finally, the difference in the level of conversion between the different investigations should be noted. There are several influencing factors outside of the present subject which may have contributed. Important to the present study is the inclination of the curves and the difference between emissions from fuels with different volatile contents.

\section{Discussion}

It is instructive to compare the well-known emission properties of pulverized coal combustion with fluidized bed combustion. Except for the possibility of thermal $\mathrm{NO}_{\mathrm{x}}$ production in a PC flame, there are two major differences related to fuel volatiles. The first difference concerns the quantity of volatile nitrogen released during devolatilization. It is known, e.g. from the results of Pohl and Sarofim, ${ }^{13}$ that 
under fluidized bed conditions (i.e. low temperature) the fractional yeild of fuel- $\mathrm{N}$ upon devolatilization is directly proportional to the volatile fraction, but at the higher temperature of PC combustion the fractional fuel- $\mathrm{N}$ exceeds that of the volatile and can reach $70-80 \%$ for a $35 \%$ ASTM volatile coal. The second characteristic property of PC combustion is that these large amounts of volatile nitrogen compounds either tend to be oxidized to NO or contribute to the reduction of previously produced NO in a complicated network of gas phase reactions depending on the local conditions (oxygen concentration and temperature). As a result, unstaged flames from fuels with high volatile content tend to have a larger conversion to NO than those from fuels with a low volatile content, whereas the order is reversed when air staging is used to take advantage of the volatile nitrogen compounds to reduce the NO emission. This is illustrated by Fig. 6 which is based on the work of Kremer and Schulz. ${ }^{14,15}$

Considering the differences in amount of volatiles released and temperature, this information can be translated to the freeboard of an SFB boiler, and it supports the description just given of the role of volatiles in an SFB. The arrangement of the air supply to the bed becomes important not only to produce volatile nitrogen which can react in the freeboard but also to increase the concentration of char in the bed. The importance of secondary air in stationary fluidized bed combustors was investi-

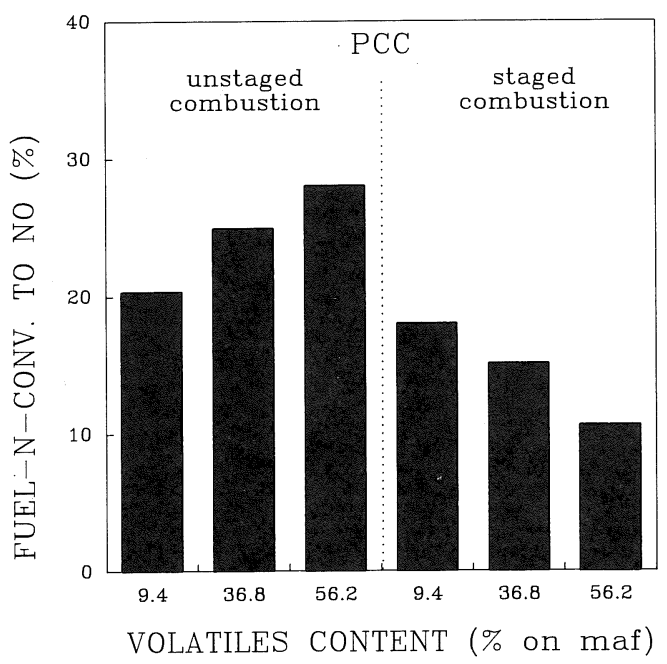

FIG 6. Influence of fuel volatiles on the conversion ratio of fuel nitrogen to NO. Pulverized coal combustion. Fuels: Anthracite, bituminous coal and brown coal. Excess air ratio $=1.35$. Primary air stoichiometry at staged air supply $=0.90$. Re-written from data in ref. 14 and 15. gated already in $1977 .{ }^{16}$ In addition, specially for high volatile fuels, the contact between air and volatiles in the freeboard becomes decisive for the formation or destruction of NO.

The situation in a CFB is different. Due to the high particle loading in the furnace, the reactions producing or reducing NO from volatile nitrogen compounds are greatly influenced by particle surfaces. The present results do not give definite information about the influence of volatiles, but it is quite obvious that the positive effects noticed in the $\mathrm{SFB}$ are absent or of small importance. Instead, it seems that in the CFB the influence of char dominates the reduction of NO. This would explain why high volatile fuels are less effective in the CFB. For this reason, air-staging may not be as efficient in reducing $\mathrm{NO}$ as it is the $\mathrm{SFB}$. In fact, in some $\mathrm{CFB}$ designs air staging has no effect at all [Åmand \& Leckner $\left.{ }^{17}\right]$. More efficient ways to increase the char reaction surface for NO reduction would be to increase the presence of very fine char particles by fly-ash recirculation. The result from such an experiment in the present boiler is shown in Fig. 7 .

The judgement of the role of nitrogen-containing volatiles in CFBs or SFBs is further supported by experiments with ammonia injection. Ammonia can be taken as a representative substance for the nitrogen-containing volatiles. Injection of ammonia in the dense bed of an $\mathrm{SFB}$ or in the combustion chamber of a CFB boiler is known to have a small and even negative effect on the emissions of NO [Hampartsoumian \& Gibbs, ${ }^{18}$ Amand \& Leckner ${ }^{19}$ ]. The ammonia is broken down by the char and other bed particles. Injection into the splash zone or the lower part of the freeboard of an SFB boiler, on the other hand, yields a substantial reduction of NO.

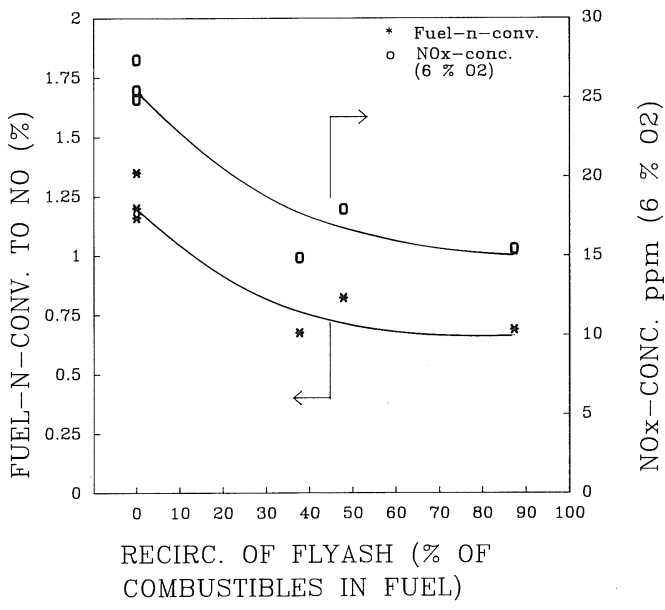

FIG. 7. Reduction of the NO emission by fly ash reinjection in the Cityvarvet $\mathrm{CFB}$ boiler. 


\section{Conclusions}

The NO emissions from fluidized bed combustors are less dominated by the properties of volatile fuel nitrogen compounds than pulverized coal combustion.

The NO emissions from the stationary type of fluidized bed boiler are decreased by the volatile fuel nitrogen, whereas in the circulating type of fluidized bed boiler the NO emissions tend to increase with high volatile fuels.

The measures to reduce the NO emissions should take advantage of these tendencies: where the volatiles are important, the air supply becomes important; where the char is important, factors which increase the char reaction surface become important (for instance fly ash recirculation, total excess air ratio, etc).

\section{Acknowledgment}

This work has been financially supported by the Swedish National Energy Administration.

\section{REFERENCES}

1. Hampartsoumian, E. and Gibbs, B. M.: J. Inst Energy 57, 402 (1984).

2. Furusawa, T., Ishikawa, S., Sudo, S. and KuNII, D.: J.CHEM.Eng.Japan 16, 76 (1983).

3. Wittler, W., Schütte, K., Rotzell, G. AND SCHÜGERL, K.: Chem.Ing.Tech. 60, 420 (1988).

4. AsAI, M. AND SHImoda, H.: 1st Korean-Japanese Symposium on Fluidization, Seoul, 1988.

5. Asai, M., AoKI, K., Oda, Y. and Shimoda, H.: 2nd SCEJ Symposium on Fluidized Beds, p.101, Chemical Engineers of Japan, Tokyo, 1988.

6. Suzuki, T., Ishizuka, H., Hyvarinen, K., Morita, A., Yano, K. and Hirose, R.: 2nd SCEJ Symposium on Fluidized Beds, p.109, Chemical Engineers of Japan, Tokyo, 1988.

7. Shimuzu, R. and Furusawa, T.: 3rd SCEJ
Symposium on Fluidized Beds, p.134, Chemical Engineers of Japan, Tokyo, 1989.

8. LeE, Y. Y. AND Hiltunen, M.: Joint Symposium on Stationary Combustion $\mathrm{NO}_{\mathrm{x}}$ Control, EPRI/EPA, San Francisco, 1989.

9. Legros, R., Brereton, C. M. H., Lim, C. J., LI, H., Grace, J. R. and Anthony, E. J.: 10th International Conference on Fluidized Bed Combustion, (A. M. Manaker, Ed.), Vol.2, P.661, ASME Book No 10290A, 1989.

10. ÅmAND, L-E. AND ANDERsson, S.: 10th International Conference on Fluidized Bed Combustion (A. M. Manaker, Ed.), Vol.1, p.49, ASME Book No 10290A, 1989.

11. Hirama, T., Tomita, M., Horio, M., Chiba, T. AND Kobayashi, H.: 4th International Conference on Fluidization (D. Kunii and R. Toei, Eds), Vol.1, p.467, Engineering Foundation Book No 83-83069, 1984.

12. Tatebayashi, J., OKada, Y., Yano, K. AND IKeda, S.: 6th International Conference on Fluidized Bed Combustion, Vol.3, p.986, U.S. Department of Energy No 800428, 1980.

13. Pohl, J. H. AND SARofim, A. F.: Sixteenth Symposium (International) on Combustion, p.491, The Combustion Institute, 1977.

14. Kremer, H. and Schulz, W.: Twenty-First Symposium (International) on Combustion, p.1217, The Combustion Institute, 1988.

15. SChulZ, W. AND KREMER, H.: Brennstoff-WärmeKraft, 37, p.29, 1985

16. Gibbs, B. M., Pereira, F. J. and Beér, J. M.: Sixteenth Symposium (International) on Combustion, p.461, The Combustion Institute, 1977.

17. Åmand, L-E. AND LECKNeR, B.: Second International Conference on Circulating Fluidized Bed Boilers, p.457 (P. Basu. and J. F. Large, Eds), Pergamon Press, 1988.

18. Hampartsoumian, E. and Gibbs, B. M.: Nineteenth Symposium (International) on Combustion, p.1253, The Combustion Institute, 1982.

19. Åmand, L-E. AND LECKNER, B.: 1st European Conference on Industrial Furnaces and Boilers (R. Collin, W. Leuckel, A. Reis and J. Ward, Eds), INFUB, Lisbon, 1988. 